821.111(73).09 Updike J.

https://doi.org/10.18485/bells.2019.11.7

\title{
Pradipta Sengupta*
}

M.U.C.Women's College Burdwan

West Bengal, India

\section{PSYCHIC SEXUALITY: MEMORY AND DREAM IN JOHN UPDIKE'S VILLAGES}

\begin{abstract}
Only a very few writers have explored the full gamut of middle-class suburb life, warts and all, as John Updike, and even fewer have run the whole gamut of sexual experience as he has. With his avowed preoccupation with the "three secret things" of sex, religion, and art, Updike has examined the single aspect of sexuality through varied reference frames at varying stages of life: boyhood, adolescence, manhood, and old age. If A Month of Sundays and S. offer a ritualization of sexuality, Roger's Version offers a scopophilic examination of sexuality in terms of the sexual phantasizings of Roger Lambert. Updike's Villages (2004) reemploys the use of sexuality on different spatio-temporal parameters, chronicling the kaleidoscopic ken of the old Owen Mackenzie's sexual encounters, reminisced and replenished through his memories and dreams, and operating on his psychic planes. Lured and intrigued by the "monstrous miracle" of sex, Owen experiences a thrill analogous to a conquest in his erotic adventures with a battalion of mistresses, and his wives. And yet his is not a case of gerontophilia, for in his present dotage he is more interested in relishing those libidinal experiences in his memories than in having further erotic advances. Updike deals with Owen's psychic sexuality in an artistic way that dovetails into his present old age. At once a faint autobiographical projection of Updike, and a dim shadow of his early heroes turned old, Owen prefers contemplation of the carnal carnival to direct action. Applying the insights of Psychoanalysis, this paper would seek to analyse and justify the nature of these memories and dreams to suggest how Updike reckons with sexuality with greater
\end{abstract}

E-mail address: pradiptasg.eng@gmail.com 
panache evinced through the psychic lens of an aged hero who remains satisfied with erotic emotions recollected in tranquillity.

Keywords: psychic, sexuality, sex, memory, dream, phantasizings, Updike, Villages, aged, autobiographical

Of the "three great secret things" sex, religion, and art, it is the treatment of sexuality of which Updike was a true connoisseur. Updike has examined the single aspect of sexuality through varied reference frames at varying stages of life: boyhood, adolescence, manhood, and old age. If A Month of Sundays and $S$. offer a ritualization of sexuality, Roger's Version offers a scopophilic examination of sexuality in terms of the sexual phantasizings of Roger Lambert. Updike's Villages (2004) reemploys the use of sexuality on different spatio-temporal parameters, chronicling the kaleidoscopic ken of the old Owen Mackenzie's sexual encounters, reminisced and replenished through his memories and dreams, and operating on his psychic planes. Updike deals with Owen's psychic sexuality in an artistic way that dovetails into his present old age. At once a faint autobiographical projection of Updike, and a dim shadow of his early heroes turned old, Owen prefers contemplation of the carnal carnival to direct action. The fact that Updike had his divorce from his first wife Mary Pennington in 1976, and that he remarried Martha Ruggles Bernhard in 1977, make Villages a significant element in Updike's second conjugal innings, as also in his oeuvre. It is at once Updike's autobiographical journey down his memory lane to review his life after almost three decades, and an attempt to examine sexuality through the lens of an aged hero who finds an alternative for his diminished sexuality in the phantasizings, memories, and dreams of his previous erotic encounters. Commenting on Updike's treatment of sexuality, Brian Duffy argues, "Villages has the added relevance of being Updike's last extended examination of the topic, and even has a valedictory ring about it", and examines the novel as a representation of male sexuality (Duffy 2015: 3). This paper attempts to analyse and justify the nature of these memories and dreams to suggest how Updike reckons with sexuality with greater

1 In his memoir "The Dogwood Tree: A Boyhood" Updike refers to his preoccupation with "three great secret things", namely sex, religion and art. Interested readers may find this memoir in Updike's Assorted Prose (See Updike 1979: 151-187). 
panache evinced through the psychic lens of his aged hero who remains satisfied with erotic emotions recollected in tranquillity.

Villages elicited rather lukewarm responses from reviewers and critics. Adam Begley in his biography of the author Updike (2014) calls it "a doggedly autobiographical retelling of Updike's progress from Shillington... to Beverly Farms...." (Begley 2014: 457). In his review of the novel Begley relegates it to a novel where there is no scope of novelty: "Nothing happens that hasn't happened elsewhere in the vast oeuvre; no new kind of character is introduced; no new landscape limned." ${ }^{2}$ Brian Duffy in his article "Male Sexuality in John Updike's Villages" contends, "One failing of Villages was deemed to be Updike's returning again to the adulterous adventures of the middle-class suburban American male, with the implication that sex is not only the overbearing force but the overriding value in adult male life" (Duffy 2015: 2). While Peter Bailey refuses to consider Villages "among Updike's most successful novels", he does not fail to point out the parallels between Owen's life and that of his author (Bailey 2013: 83). Following in the same line as Begley and Bailey, Schiff contends: “Owen's story stands as a lightly fictionalized version of Updike's own life, as he moved from a Pennsylvanian boyhood in Shillington, to young married life and adultery in Ipswich, to his final, more remote existence in Beverley Farms" (Schiff 2017: 82). Marshall Boswell hails the novel as "a dispassionate novel that mixes nostalgia with a cool biological fatalism that is utterly free of existential anxiety or the fear of nothingness" (Boswell 2017: 72). Aristi Trendel insists on reading it as a novel of seduction, and claims that it is "Updike's twenty-first century contribution to Don Juan's literary myth and an homage to the vitality of seduction in all its forms" (Trendel 2017: 102). Michiko Kakutani ${ }^{3}$ in her review of Villages contends: "In the end, this all makes for a narrow, claustrophobic novel - a novel that amounts to a little more than a weary exercise in the recycling of frayed and shop-worn material". Yet, what Kakutani fails to notice is that there is not a single novel in Updike's lurid oeuvre where sexuality is vicariously replenished as a second-hand experience in terms of being reminisced through memories and replicated through dreams.

2 Adam Begley (2004), "It Takes a Village, or Three". Rev. of Villages, by John Updike. New York Observer 25 Oct. 2004: 10.

3 Michiko Kakutani (2004), "Another Updike Trip to His Kind of Suburbia”. Rev. of Villages, by John Updike. New York Times 22 Oct.2004: E 33. 
Interestingly, Updike himself was not optimistic about Villages. As Updike admits in an interview ${ }^{4}$ :

This present novel that will be out-Villages - I several times thought it might be a bad idea and kind of abandoned it. So, it was really the habit - the habit of writing that kept me at it in the end. It was like a bad marriage....This is the wife I'm married to here, and I'm going to finish this book. Finishing it becomes the only way to get rid of it.

And yet, far from being "a bad marriage" Villages turns out to be an artistic novel, for Updike deals with Owen's psychic sexuality in an artistic way that dovetails into his present old age. And yet his is not a case of gerontophilia, for in his present dotage he is more interested in relishing those libidinal experiences in his memories than in having further erotic advances.

At once a faint autobiographical projection of Updike, and a dim shadow of his early heroes turned old, Owen prefers contemplation of the carnal carnival to direct action. Updike accounts for the rather tepid responses to his novel. As he contends in his essay "The Writer in Winter": "An aging writer wonders if he has lost the ability to visualize a complete work, in its complete spatial relations.... [H]e may arrive at his ending nonplussed, the arc of his intended tale lying behind him in fragments. The threads have failed to knit" (Updike 2012: 5).

Donald Greiner ${ }^{5}$ considers Villages Updike's "most thoroughly nostalgic novel of sweethearts, wives, and mistresses", and this observation borders on Updike's pervasive use of memory in the novel (Greiner 2015: 47). What most of the reviewers and critics have overlooked is the exact function of dreams and memories in this novel. Among the research devoted to Villages it is Schiff's article "Dreams, Conflated Wives, Lingering Guilt, and Coitus Recalled in Updike's Villages" that comes close to my line of argument. But while Schiff enumerates on the dreams of Owen, what he has overlooked is how the very plot of this novel exhibits certain traits of a dream. My humble claim in this paper is that dreams in Villages are more functional than informative, more artistic than decorative. Villages bears ample resemblance to the mysterious nature of human psyche, the

4 John Updike (2004), "Showing Ordinary Life as Being Worth Writing About It". Interview. Academy of Achievement. 12 June 2004. Web 18 Oct. 2018. <http://www. achievement. org/autodoc/page/updoint-1>.

5 Donald Greiner (2015), "Updike in Love". John Updike Review 4.1 (Fall 2015): 43-60. 
fountain of human memory and dream. The plot and the narrative exhibit conspicuous resemblances to the traits of dream.

\section{II}

Dream has fascinated human beings since time immemorial. Aristotle in De divination per somnum, II and De Somniis, III suggests that dreams offer a magnified version to the small stimuli of life. He further contends that dreams emanate not from gods, but from demons. What he implied was that the human mind, the fountain of every dream, is more demonic than divine. In his groundbreaking research The Interpretation of Dreams Freud claims that "Aristotle was aware of some of the characteristics of dreamlife. He knew, for instance, that dreams give a magnified construction to small stimuli arising during sleep" (Freud 2010: 42). Freud refers to a host of critics who helped shape his theory. In his famous The Interpretation of Dreams Freud cites the examples cited by Delboeuf to substantiate the concept of "hypermnesic" dreams. As Freud observes: "No one who occupies himself with dreams can, I believe, fail to discover that it is a very common event for a dream to give evidence of knowledge and memories which the waking subject is unaware of possessing" (Freud 2010: 56). Thus, dreams do have some connections with reality, and contain a sense of verisimilitude. In other words, dream is another version of the same reality which is experienced by the waking subject. What the waking subject sees at the conscious level, takes the form of an impalpable dream at the subconscious level in the form of one's dreams.

Freud refers to Strumpell $(1877,40)$, and quotes him to substantiate the inalienable connection between dream and memory:

The position is even more remarkable when we observe how dreams sometimes bring to light, as it were, from beneath the deepest piles of debris under which the earliest experiences of youth are buried in later times, pictures of particular localities, things or people, completely intact and with all their original freshness. (Freud 2010: 57-58)

The "deepest piles of debris" that Strumpell metaphorically speaks of are the memories buried deep in the human psyche. Another critic who intuits this connection between dream and memory is Hildebrant $(1875,23)$ : "I have already expressly admitted that dreams sometimes bring back to our 
minds, with a wonderful power of reproduction, very remote and even forgotten events from our earlier years" (Freud 2010: 57). Striking a very similar note, Volkelt $(1875,119)$ argues: "It is specially remarkable how readily memories of childhood and youth make their way into dreams. Dreams are continually reminding us of things which we have ceased to think of and which have long ceased to be important to us" (Freud 2010: 58). Any perceptive reader cannot but notice that the point of commonality among all these critics is the interface between dream and memory which are inextricably enmeshed in the human psyche.

Freud divides dream theories into three categories. The first brand is espoused by critics like Delboeuf whose theories suggest that "the whole psychical activity continues in dreams. The mind, they assume, does not sleep and its apparatus remains intact; but since it falls under the conditions of the state of sleep, which differ from those of waking life, its normal functioning necessarily produces different results during sleep" (Freud 2010: 129). If the first brand believes that the mind can retain its psychical wholeness during dream, the second brand of theories is just its opposite, and these theories "presuppose that dreams imply a lowering of psychical activity, a loosening of connections, and an impoverishment of the material accessible" (Ibid.). The third brand refers to "those theories which ascribe to the dreaming mind a capacity and inclination for carrying out special psychical activities of which it is largely or totally incapable in waking life" (Freud 2010: 137). My humble attempts in this paper will be to substantiate how some of the basic traits of dream - condensation, displacement, translation of thoughts into visual images, etc. — are evident in Updike's Villages, and how the novel employs dreams and memories in an artistic way.

III

Updike had made sporadic use of dream in his oeuvre. In Rabbit, Run while making love with Ruth, Rabbit dreams of his sister Mim getting dissolved into his wife Janice. Haunted by the dissatisfaction of a second-rate marriage, Rabbit dreams of appearing before a court where his mother is the judge. Rabbit's mother Mary is haunted by some horrible dreams induced by the effects of L-Dopa in Rabbit Redux. In Couples, a novel which along with Marry $\mathrm{Me}$, can be said to be literary precedents of Villages, Piet dreams of flying in a luxurious plane (Updike 1968: 284-285). Dream also makes 
its presence so valuable in Updike's poems "Dream Objects", "The Play of Memory" (in Midpoint) \& "Dream \& Reality". In the Argument of "The Play of Memory", for example, Updike claims that "[t]he poet remembers and addresses those he has loved". This is followed by a funny and erotic focus on their anatomy (Updike 1995: 81).

\section{IV}

Reflecting on the wantonness of the three divorcees in The Witches of Eastwick, Lurie Alison observes: "It is to Updike's great credit, and a proof of his long-standing ardent interest in women, that he is also interested in and deeply sympathetic to their experience of age" (Qtd. in Begley 2014: 469). This comment may be equally extended to Villages with the difference that his interest lies more in his aged hero than his heroines. Commenting on the differences between Hawthorne and Updike, Donald Greiner in his Adultery in the American Novel: Updike, James, and Hawthorne cogently points out the difference of punishment being one of the major differences among the adulterers of the two authors:

A primary difference is the punishment exacted. Hurl the charge of sexual transgression against Rabbit, Piet, Jerry, or Marshfield, and they will retreat to the next suburb or even to their imaginations. (Greiner 1985: 57) (Emphasis mine)

Interestingly, while Greiner made this comment almost two decades prior to the publication of Updike's Villages, it is all the more applicable to Owen who resorts to his imagination and memory to redress his diminishing sexual faculty, and through them recollects how he had sexual liaisons with a battalion of mistresses in three different locales of the novel: Willow, Pennsylvania; Middle Falls, Connecticut; and Haskells Crossing, Massachusetts.

In Updike's Villages the retired software engineer Owen Mackenzie is ensconced steadily with his second wife Julia Larson at Haskel Crossings, Massachusetts. Interestingly, Updike's Villages begins with and ends with Owen's recollection of his previous sexual encounters in his memory. In fact, at the very outset Owen "dreams that, he is in a house that he doesn't know" (Updike 2004: 4), and this is followed by "[t]he image of his beloved lying naked and dead in his dream", "the dream stems from 
a guilty sensation" (Ibid.6). Similarly the first inkling of Villages being a novel about psychic sexuality, rather than its physical counterpart, is hinted at from the very outset when Owen "finds the way back to sleep only by remembering one of the women, Alissa or Vanessa or Karen or Faye, who shared with him the town of Middle Falls, Connecticut, in the 'sixties and 'seventies (Ibid.5). Contemplating everything "in his mind's eye", Owen delves into a series of memories and dreams which form the major narrative trope of the novel (Ibid.9). And when we come to the end of the novel we find Owen's disrupted sleep, as he suddenly wakes up early at three in the morning, and after a futile masturbatory attempt, slides into a wistful journey across his memory lane: "in his mind's eye he runs the images of those moist, knowing engulfments, those grotesque postures of submission, but, just when he almost has it, has it in hand, the temperature or edge or whatever it is unexpectedly slithers away....The workable parameters, once so broad there was ample room for fatigue and ambivalence, draw in. At the far extreme of his pilgrimage, the selfinduced orgasms of early adolescence recede" (Ibid. 320). And between the beginning and the end the recollections of Owen's self-projected memories of his earlier carnal carnival, his erotic phantasizings, and a host of dreams shuttle and scuttle across his psychic plane, and flesh out the corpus of the narrative of the novel.

In one of the major dreams that Owen shares with his wife Julia, "he dreamed that, standing on the sea side of their white house, he saw her go off, in her black BMW, on one of her innumerable errands to Boston", and when he follows her in his Mitsubishi, "driven not by him but by Julia again, her pale profile preoccupied. His first wife, Phyllis, had also held her head in this tense, eye-catching way when behind the wheel- tipped slightly back as if in anticipation of the engine's exploding" (Ibid.35, 36). In his dream he comes back to the house where he meets "a family of three Chinese, identical, blobby, like inflated dolls or swollen gray ticks", and becomes confused as to how to receive them in Julia's absence (Ibid. 36). If Freud in The Interpretation of Dreams suggests that dreams are capable of bringing back buried memories to the surface, Owen's overt married life with his first wife Phyllis, looms large over his consciousness, and creates a muffled vision which flits between Julia and Phyllis in his dream vision. Later Owen is visited by a strange dream in which he finds himself in a party at Middle Falls, where the unfamiliarity of the ambience, along with the unfamiliar women, strikes him: in the dream he slowly 
notices how the two female guests he is talking to, one of them seated beside him and the other standing, are both dressed in painted china, rigid carapaces with shiny sculptural edges, as if they are eighteenth-century figurines" (Ibid.115). When discomfiture overtakes him for being "illdressed", Owen finds to his amazement that the party was hosted in "his house" on Patridgeberry Road, Middle Falls, and that he happens to be "the mysterious host, humiliatingly ill-clad with a porcelain suit" (Ibid.116). If Freud talks about the displacement in a dream, Owen's house provides the displaced space for the party. In his next major dream Owen is haunted by an apprehension of losing his wife Julia:

Somewhere in his thick net, the dream, there is his rapidly burgeoning relationship with Julia, compact, firm, decisive, surprisingly sexy Julia, but he keeps losing her, it is just too hard to keep up the precarious secret connection- the hurried, hardbreathing phone calls, the panicky trysts where the edges of this town merge with the edges of another- and weeks go by, in his dream, without any connection being made, and his love object sinks deeper and deeper beneath the surface of the everyday... (Ibid.189)

At a deeper level, it hints at Owen's subconscious fear of losing his first wife Phyllis, and ipso facto, may be related to Updike's loss of his first married life with Mary. If Phyllis is physically killed, and replaced by Julia, Mary is metaphorically obliterated from Updike's conjugal cosmos and actually replaced by Martha. In the final major dream of the novel Owen is whisked off to "some kind of classroom setting, he was delegated by the teacher to take a pencil or a textbook to Barbara Emerich, who is sitting alone in a corner, at one of those chairs with a broadened arm of yellow oak to write on" (Ibid.306). Sensing her unresponsiveness when Owen went closer, he felt "out of the shadowy space between her lap and her downturned face, that she was willing to have him kiss her. She expected it but acted on the expectation only by maintaining a stubborn stillness, her mouth clamped shut on her sunny smile, with its single grey tooth" (Ibid.307). The dream stimulates his memory of his first wife Phyllis, and brings back to his mind how at MIT, he would date with her, prior to their marriage (Ibid.307). That said, dream is also a strong stimulant of memory, and this is amply attested to by this dream.

Apart from forming the texture of this novel, the dreams and the mellifluous memories of Owen's sexual encounters, serve some aesthetic 
functions in Villages. The narrative itself exhibits resemblances to the nature of a dream: condensation, displacement, and so forth. If displacement is a prominent feature of any dream, the narrative gives ample evidences of spatio-temporal dislocations, both in the life of Owen and his author. In fact, the very plot of the novel may be read as a displaced autobiography. Interestingly, Owen's life is but a faint shadow of his author, inasmuch as the three fictional places roughly dovetail into the author's boyhood, married life, and second married life, respectively. Owen's stay at Willow corresponds to the author's boyhood days in Shillington. Updike's girlfriend in the fifth grade Jackie Hirneisen ${ }^{6}$ who also appears in his short story "The Alligators", and Nancy Wolf, popularly known as Nora, whom Updike calls "my only girlfriend" , serve as the fictional counterparts of the fictional Elsie Seidel, Owen's mistress at Willow. Owen's stay at Middle Falls corresponds to the author's stay at Ipswich, Massachusetts. During this phase Updike's conjugal life with his first wife Mary Pennington was tossed and buffeted because of his adulterous liaison with Joyce Harrington. In the novel Owen is seen to have a liaison with Phyllis Goodhue whom he eventually marries. The final phase, Owen's stay at Haskells Crossing with his second wife Julia, corresponds to Updike's stay at Beverley Farms with his second wife Martha. Updike's own life gets reshaped, reoriented, displaced in this novel where spatial displacement plays a vital role, as we find in dreams. Thus Ipswich is displaced by Middle Falls, Beverley Farms by Haskells Crossing, and Harvard by MIT. Adam Begley puts it in the author's biography: "The hero, Owen Mackenzie, emerges from an idyllic small-town boyhood that is essentially indistinguishable from Updike's. Owen escapes his beloved Willow with a scholarship to MIT rather than Harvard; works at IBM rather than The New Yorker; and makes a modest fortune, after going freelance, writing software rather than literature" (Begley 2014: 468-469).

If Villages, more than any single Updike novel, deals with the human psyche, the storehouse of dreams and memories, it is Updike's tripartite setting that strikes our interest. Like the Freudian division of the human psyche into conscious, subconscious and unconscious, the novel has a tripartite setting: Willow, Middle Falls \& Haskells Crossing.

If Freud talks about the three key features of the human unconscious, namely the Id, Ego, and Superego, the three settings at three different

6 For a more informed analysis of Updike's affairs with women, see Donald Greiner (2015), "Updike in Love". John Updike Review 4.1(Fall 2015): 43-60.

7 John Updike (1989), Self-Consciousness (New York: Knopf), 37. 
phases of Owen's life loosely correspond to it. During his liaison with Elsie Seidel, at Willow, Owen's libido stemming from his Id, overtakes him, and he nibbles at the slight opportunity of enjoying the deliciousness of her anatomy: "Now, with Elsie in the car, he had real nakedness to deal with", and "[w]ith each date she gave him an inch or two more of herself that he could claim as his henceforth; there was no taking back these small warm territories" (Updike 2004: 64). This phase of Owen's life at Willow bears resemblance to what Freud calls Id. Owen's affair with Phyllis Goodhue takes a realistic turn - or what comes close to the play of Ego dominated by reality principle - when he marries her. Thus his life at Middle Falls loosely corresponds to Ego. And his final phase of married life with his second wife Julia at Haskell Crossing loosely resembles the state akin to the Freudian concept of the Superego. If Superego is guided by a morality principle, at their mature conjugal life Owen becomes more compassionate, more considerate, and more careful about his wife Julia than he used to be earlier. A sensitive and sympathetic husband, Owen, shares his dreams with Julia, and "wants to describe all this to Julia, to make her laugh" (Ibid.36). He becomes so much dependent on her that when he "discovers that Julia is out of bed, he goes forth in search of her" and becomes agog with impatience to put up with her absence (Ibid.34). Similarly when he dreams about "something dangerous in her (Julia's) speed", he grows anxious about her, and his heart leaps "in fear that she might slip on wet leaves and fatally crash" (Ibid.36, 37). Chastened and matured by the mellowness of his ripe age, he becomes sobered and mild, at least in his act, if not in his thoughts. Thus, one may be tempted to compare it with the Freudian phase induced by Superego. The younger Owen driven by the libidinal drives of Id, finds his Ego dominating his conjugal life with his first wife Phyllis, leading to their separation through her death, until he finds his Superego predominating and acting as a balancing force to lead him a complacent and relatively stable relationship with his second wife Julia in the final setting, Haskells Crossing. As Updike puts it: "Phyllis had hoisted him up into Cambridge and the snob life of the mind, and Julia into Haskells Crossing and the life of the bourgeois repose" (Ibid.317). Hopping from woman to woman, from bed to bed, Owen finally finds his solace in and settles down with his second wife Julia.

Furthermore, if the nature of dream is always intangible, and, somewhat mysterious, the same holds true of the very concept of village. Owen's previous admission that "the villages he has lived in have been sites 
of instructions" (Ibid.41), and his later realization that "A village is woven of secrets, of truths better left unstated" (Ibid.209) conceal more than they reveal. These comments border on the inexplicable nature and ways of the village, which may be interpreted as a symbolic correspondence to the mysterious nature of the human psyche in general, and to the secret ways of human dreams in particular. These villages show a strange conflation of primitivism \& modernism, i.e., of both the libidinal drives of Id \& the conscious balancing of Ego, both latent unconscious pulls and conscious checking.

"The first thing that becomes clear to anyone who compares the dream-content with the dream-though", observes Freud, "is that a work of condensation on a large scale has been carried out"(Freud 2010: 371). In this novel condensation is evinced through Updike's concept of what he calls "generic wifeliness": "Often in his (Owen's) dreams the wife-figure is ambiguous, misty-faced, and could be either woman. Phyllis, a stately dirty-blonde, had been taller, retaining from her student days a certain bohemian insouciance, and Julia, a compact, long lashed brunette, with controlled passages of frosting in her sleek coiffeure, is snappier in her dress and in her way of moving: but both acquire in his dreams a recessive generic wifeliness" (Updike 2004: 38). Similarly, rather than being an individual, Owen may be treated as a generic Updikean hero in whom we find traits of his early young heroes turned old, and whose dreams give us certain sparks of his earlier heroes like Rabbit in the Rabbit novels, Piet Hanema in Couples, Jerry Conant in Marry Me, the computer wizard Dale Kohler in Roger's Version or the artistic seducer Darryl Van Horne in The Witches of Eastwick. Owen seems to be a loose dream-like condensation of these characters put together.

For Updike, sex is becoming; self is being. Dream becomes just another means of a re-enactment of sexuality which is typically Updikean. In keeping with Owen's old age, Updike artistically deals with Owen's sexuality through contemplation rather than direct physical action. Philip Roth in The Dying Animal comments: "Sex isn't just friction and shallow fun. Sex is also the revenge on death" (Roth 2001: 69). In the final chapter of Villages, "Village Wisdom" (an evolution from "Village Sex") upholds sex as a bulwark against death. Sex has a redemptive aspect and serves as man's desperate defense against ageing and impending death. A wry rehash of Updike's cult novel Couples, almost three decades on, he takes up in Villages where he left in Couples - the same suburban adultery, but 
this time enacted on the psychic planes. But although less intense than his literary predecessors, Owen's sexual encounters are "programmed", so much attuned to his career in computer technology ${ }^{8}$.

\section{Conclusion}

Little wonder then, despite the unfavorable reviews of reviewers, and lukewarm responses of critics and scholars, Villages certainly deserves acclaim for being one of the novels in which sexuality has been given a new mould and examined from a new angle. Given the ageing of both the hero and his author, Updike's shift from the physical to the psychic also bespeaks his artistic panache and finesse. Furthermore, the dreams and memories which form the matrix of the novel are more than textural and decorative, for they serve a host of artistic purposes suited to the protagonist's temper and to the unfolding of the plot. Villages also resembles the Freudian tripartite structure of the human psyche, and shares some of the inexplicabilities of human psyche, the fountain of these dreams and memories. Like Tennessee Williams's play The Glass Menagerie which has been hailed as a "memory play", one may be tempted to suggest that Updike's Villages be hailed as a "memory novel", as Owen looks back in wonder on his previous sexual encounters. Updike's Villages turns out to be Owen's romantic ballad emanating from a spontaneous and retrospective overflow of powerful sexuality, and sung by an old man who finds solace in Eros recollected in tranquility.

\section{References}

Bailey, P. (2013). "Autobiography, Updike, and the 'Self-Serving Corruptions of Fiction"'. John Updike Review 2.2 (Spring 2013), 77-94.

Begley, A. (2004). "It Takes a Village, or Three". Rev. of Villages, by John Updike. New York Observer 25 Oct. 2004, 10.

8 One may be reminded of the computer wizard Dale Kohler in Updike's Roger's Version (1986). In this novel Rogert Lambert resembles Owen in his common penchant for indulging in sexual phantasizings. Roger's phantasizings detail Dale Kohler's putative sexual gymnastics with his wife Esther. Both these novels exhibit sexual encounters in an organized way, very much like programming of software in computers. 
(2014). Updike. New York: Harper Collins.

Boswell, M. (2017). "Programmed Delirium: Villages and the God of Multilevel Selection". John Updike Review 5.1(Winter 2017), 71-79.

Duffy, B. (2015). "Male Sexuality in John Updike's Villages". John Updike Review 4.1 (Fall 2015), 1-16.

Freud, S. (2010). The Interpretations of Dreams, trans. \& ed. James Strachey. Delhi: K.R.J. Book International.

Greiner, D. (1985). Adultery in the American Novel: Updike, James, and Hawthorne. Columbia, SC: University of South Carolina Press. 2015), 43-60.

Kakutani, M. (2004). "Another Updike Trip to His Kind of Suburbia". Rev. of Villages, by John Updike. New York Times 22 Oct.2004: E 33.

Roth, P. (2001). The Dying Animal. London: Vintage.

Schiff, J. (2017). "Dreams, Conflated Wives, Lingering Guilt, and Coitus Recalled in Updike's Villages". John Updike Review 5.1 (Winter 2017), 81-89.

Trendel, A. (2017). "Seduction in John Updike's Villages". John Updike Review 5.1 (Winter 2017), 91-104.

Updike, J. (1960). Rabbit, Run. New York: Knopf.

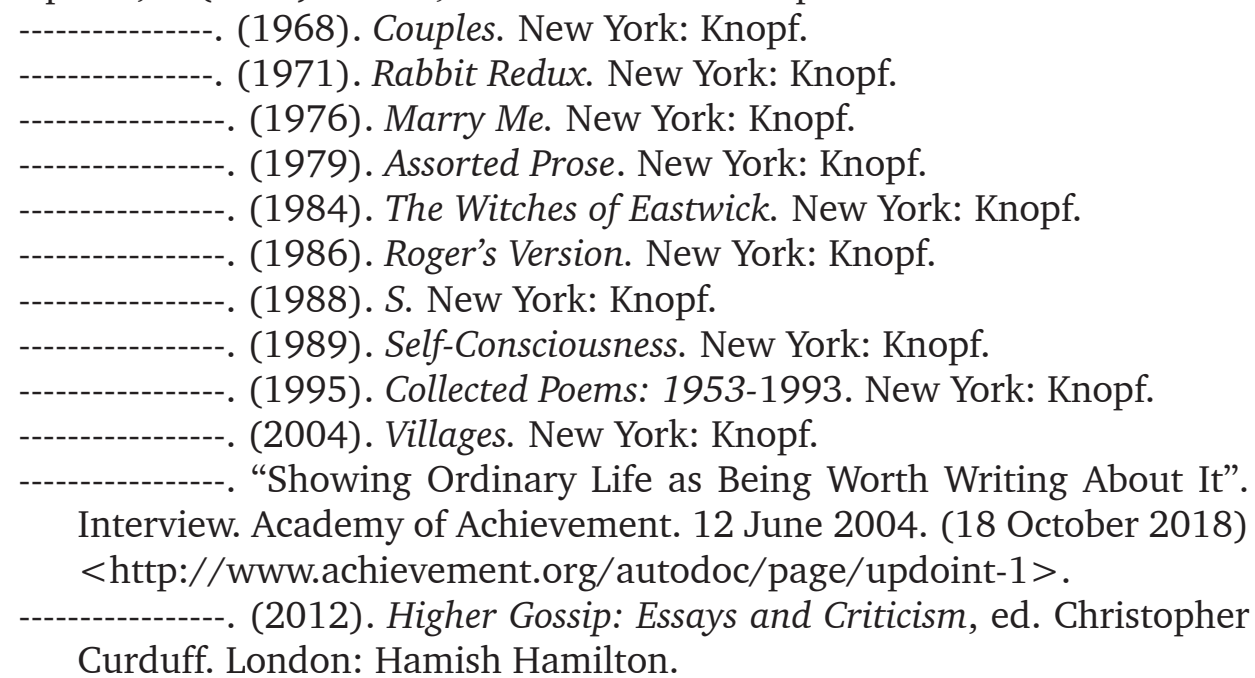

Received: 19 October 2018

Accepted for publication: 28 December 2018 
Pradipta Sengupta: Psychic Sexuality: Memory and Dream in John Updike's Villages

Прадипта Сенгупта

\author{
ПСИХИЧКА СЕКСУАЛНОСТ: СЕЋАҢЕ И САН У СЕЛИМА \\ ЏОНА АПДАЈКА
}

\begin{abstract}
Сажетак
Само неколико писаца истраживали су целокупан опсег живота предграђа средње класе, њихове вредности и остало, на начин како је то у својим делима урадио Џон Апдајк, а много је мање оних који су истраживали сексуално искуство. Будући да је носио у себи „три тајне” (секс, религија и уметност), Апдајк је испитивао појединачне аспекте сексуалности кроз разноврсне склопове референци у различитим фазама живота: дечаштву, адолесценцији, зрелости, и старости. Ако Један месеи недеља и С. нуде ритуализацију сексуалности, Роцерова верзија нуди скопофиличко истраживање сексуалности у погледу сексуалног фантазирања Роџера Ламберта. Апдајкова Села (2004) поново уводи термин сексуалност са различитим просторно-темпоралним параметрима, и даје преглед каледиоскопског видокруга сексуалних сусрета старог Овена Мекензија, које поново оживљава кроз сећања и снове, а која делују на психолошком плану. Привучен и опчињен „монструозним чудом” секса, Овен доживљава узбуђење које је аналогно освајању у његовим еротским авантурама са батаљоном љубавница, и својим женама. Па ипак, није у питању геронтофилија, јер га у тренутку старачке изнемоглости више занимају уживања у либидиналним доживљајима у сопственим сећањима него у новим еротским освајањима. Апдајк се бави Овеновом психичком сексуалношћу на уметнички начин. У тренутку када бледа аутобиографска пројекција Апдајка и нејасна сенка његових раних јунака остари, Овен више воли да размишља о телесном карневалу. Примењујући психоанализу, у овом раду ћемо покушати да анализирамо и оправдамо природу ових сећања и снова да бисмо показали како Апдајк гледа на сексуалност са великим еланом који се препознаје кроз психичка сочива остарелог јунака који је задовољан еротским емоцијама којих се у спокоју сећа.
\end{abstract}

Кључне речи: психички, сексуалност, секс, сећање, сан, фантазирање, Апдајк, Села, остарели, аутобиографски 